\title{
CHANGES IN THE CHEMICAL STRUCTURE AND DECAY RESISTANCE OF HEAT-TREATED NARROW-LEAVED ASH WOOD
}

\author{
Mesut Yalcin $^{1}$, Halil Ibrahim Sahin ${ }^{1, \AA}$
}

\begin{abstract}
We analyzed the effects of heat treatment on the chemical structure of wood from narrow-leafed Ash (Fraxinus angustifolia), a fast-growing and economically valuable species. We also analyzed the effects of heat treatment on the wood's resistance to four decay fungi. Narrow-leafed Ash wood samples were heated with saturated steam to $140,180,200$, and $220^{\circ} \mathrm{C}$ for 2,4 , and $6 \mathrm{~h}$. The relative contents of extractable components were analyzed, as well as the levels of holocellulose, cellulose, and lignin. In addition, the density, equilibrium moisture content, and $\mathrm{pH}$ of the samples were measured. To determine the effects of heat treatment on resistance to decay fungi, the samples were exposed to the white rot fungus Trametes versicolor, dry rot fungus Serpula lacrymans, and the brown rot fungi Coniophora puteana and Gloeophyllum trabeum. Changes in the chemical composition of the wood due to heat treatment were correlated with increased resistance to fungal decay. While the hemicellulose content was dramatically reduced with increasing temperature and treatment duration, the lignin content increased proportionately. Thus, heat treatment is an environmentally friendly method of preserving narrow-leafed Ash wood against various decay fungi.
\end{abstract}

Keywords: Chemical structure, decay resistance, Fraxinus angustifolia, thermal modification.

\section{INTRODUCTION}

A variety of mechanical, chemical, and biological factors can lessen the durability of wood products, leading to economic losses, and the cutting of trees to replace destroyed wooden materials adds to the threat of deforestation (Calonego et al. 2010).

Under suitable climatic conditions, wooden materials face biological degradation due to various organisms, which feed on the natural polymers (Paes et al. 2004). To extend the life of wood, a number of methods have been developed, including various modification processes and treatment with wood-protecting substances (Oliveria 1986). However, the use of wood preservatives is often limited or banned due to environmental pressures (Kartal et al. 2004). Therefore, environmentally friendly methods to preserve wood are needed (Hill 2006, Cao et al. 2011). Heat treatment is one such method that is effective against wood decay fungi (Esteves and Pereira 2009).

Heating has been shown to improve the dimensional stability (González-Peña et al. 2004, hygroscopicity (Hakkou et al. 2005), and decay resistance (Homan et al. 2000) of wood, but it weakens wood's mechanical properties (Viitaniemi et al. 2002). Hemicellulose, amorphous cellulose, and lignin are subject to degradation or modification, and the extractives evaporate or polymerize (Viitaniemi et al. 2002). Thermal modification alters the chemical properties of wood (Weiland and Guyonnet 2003), making heat-treated wood more resistant to decay (Lekounougou et al. 2009). The optimal temperature and time of such heat treatment varies among non-naturally resistant wood species (Kamdem et al. 2002, Calonego et al. 2010).

\footnotetext{
' Faculty of Forestry, Forest Products Engineering Department, Duzce University, 81620 Duzce, Turkey.

^Corresponding author: halilibrahimsahin@duzce.edu.tr

Received: 07.03.2014 Accepted: 31.08.2014
} 
Narrow-leafed Ash (NLA) is a fast-growing tree that is commonly cultivated on plantations (Cicek and Yilmaz 2002). Its wood is used in many products, including furniture, flooring, sports equipment, wainscoating, and cladding panels (Bozkurt and Erdin 1989). However, the wood's low natural resistance to decay organisms shortens its useful life. Therefore, we examined the effect of heat treatment on the service life of NLA wood and its resistance to decay fungi. This is the first such study to date.

\section{MATERIALS AND METHODS}

\section{Wood samples}

Three narrow-leafed Ash (Fraxinus angustifolia Vahl) trees, each approximately 22 years old, were randomly selected from Düzce Province, Turkey. Timber ( $1 \mathrm{~m} \mathrm{long}$ ) cut from $1.5 \mathrm{~m}$ heights of the trees were air-dried away from direct sunlight. All test samples were prepared from the sapwood, which comprises a large part of NLA (Bozkurt and Erdin 1989).

\section{Heat treatment}

The specimens were dried to approximately at $3 \%$ moisture content in a drying oven at $80^{\circ} \mathrm{C}$ for $24 \mathrm{~h}$. Then, using saturated steam, the samples were heated to $140,170,200$, and $220^{\circ} \mathrm{C}$ for 2,4 , and $6 \mathrm{~h}$. After heat treatment, the oven temperature was reduced to $20^{\circ} \mathrm{C}$, as recommended by Hakkou et al. (2006). The percent anhydrous mass loss due to heat treatment was calculated as

$$
\text { Mass loss }(\%)=\frac{m_{0}-m_{1}}{m_{0}}
$$

where mo and $\mathrm{m} 1$ are the masses $(\mathrm{g})$ before and after heat treatment, respectively. The densities of the samples were calculated as

$$
\text { Density }=\frac{m}{v}
$$

where $\mathrm{m}$ is the mass $(\mathrm{g})$ of the sample and $\mathrm{V}$ is the volume $\left(\mathrm{cm}^{3}\right)$ of the wood blocks. The pH (TAPPI T 509 om-83) and densities (TS 2472) of the heat-treated samples were compared with those of the air-dried and oven-dried untreated samples (control).

\section{Decay test}

Decay resistance tests were conducted according to the European standard (1996) EN 113 . Control and heat-treated test specimens were dried at $80 \pm 2^{\circ} \mathrm{C}$ for $24 \mathrm{~h}$ and then weighed to $0.01 \mathrm{~g}$ precision. The blocks were sterilized by autoclaving at $100 \pm 2^{\circ} \mathrm{C}$ for $20 \mathrm{~min}$. The samples were then exposed to the white rot fungus Trametes versicolor (L: Fr.) Pilat. (FFPRI 1030), the brown rot fungi Coniophora puteana (Schum.:Fr.) Karst. (Mad-515) and Gloeophyllum trabeum (Pers.) Murrill (Mad-617-R), and the dry rot fungus Serpula lacrymans (Merilius lacrymans) (Wulf. ex Fr.) (FPRL 12C). All fungal cultures were obtained from Forest Products Laboratory (Madison, WI, USA). Trametes versicolor and G. trabeum were grown on 3.9\% potato dextrose agar medium, while $C$. puteana and S. lacrymans were grown on 3.7\% malt extract agar medium. The Petri dishes $\left(9 \mathrm{~cm}\right.$ in diameter) were filled with $15 \mathrm{ml}$ of the sterile culture medium $\left(121 \pm 1^{\circ} \mathrm{C}\right.$ for $\left.30 \mathrm{~min}\right)$ and incubated with a piece of mycelium at $24^{\circ} \mathrm{C}$ and $75 \%$ relative humidity for one week. After inoculation, samples of the heat-treated and control wood $(30 \times 15 \times 5 \mathrm{~mm}$ [longitudinal $\mathrm{x}$ radial $\mathrm{x}$ tangential directions]) were placed in the Petri dishes, with a feeder strip laid across the samples to foster growth of the mycelium on the samples. After 12 weeks, the samples were cleaned of the fungal mycelia and weighed to calculate the moisture content. The samples were then dried at $80 \pm 2^{\circ} \mathrm{C}$ for $24 \mathrm{~h}$ and weighed to calculate the percentage of mass loss. 


\section{Determination of the chemical composition of the wood}

Chemical analyses were conducted to compare the chemical composition of the heat-treated and control Ash wood samples. The wood samples were chipped and ground into powder using a laboratory-scale Wiley's mill (TAPPI T $257 \mathrm{~cm}-85$ ), and the moisture content of the sawdust was determined (TAPPI T $264 \mathrm{om}-88$ ). The ground samples were then analyzed for extractable [hot water (TAPPI T $207 \mathrm{om}-88$ ), cold water (TAPPI T 207 om-88), 1\% NaOH (TAPPI T 212 om-88), and alcohol-benzene (TAPPI T 204 om-88)] lignin (TAPPI T 222 om-88), holocellulose (Wise and Karl 1962), and cellulose (Kurschner-Hoffer method, Browning 1967). The hemicellulose content of the samples was determined by subtracting of cellulose content from holocellulose (Pettersen 1984). Each experiment was carried out in triplicate.

\section{Statistical analyses}

Statistical analyses were performed using SPSS 19 software. The effects of treatment temperature and time on mass loss, wood density, chemical changes, and decay resistance were evaluated using an ANOVA and Duncan's comparison test.

\section{RESULTS AND DISCUSSION}

Table 1 shows $\mathrm{pH}$ values, densities of air-dried and oven-dried, mass loss for treated and untreated NLA wood samples. The $\mathrm{pH}$ of the untreated wood was 5.7. The $\mathrm{pH}$ decreased with increasing temperature, with the maximum change ( $\mathrm{pH} 3.9)$ occurring after treatment at $220^{\circ} \mathrm{C}$ for $6 \mathrm{~h}$.

The mass loss of the heat-treated wood correlated roughly with the treatment temperature and duration. Little mass was lost until the temperature reached $200^{\circ} \mathrm{C}$, at which point the mass loss increased rapidly. The duration of heat treatment had no significant effect on the mass lost up to $180^{\circ} \mathrm{C}$. Mass losses at this temperature result from the degradation and evaporation of wood components during heat treatment (Viitaniemi and Jämsä 1996). At temperatures above $200^{\circ} \mathrm{C}$, the cellulose and hemicellulose (the main components of the wood) are degraded, and lignin is condensed (Sundqvist et al. 2006, Tumen et al. 2010). Hence, an accelerated loss of mass was observed at treatment temperatures of $200^{\circ} \mathrm{C}$ and higher.

The wood density was inversely correlated with treatment temperature and duration. The lowest densities occurred in samples treated at $220^{\circ} \mathrm{C}$ for 4 and $6 \mathrm{~h}$ (Table 1). The difference between these samples and the control samples was statistically significant $(\mathrm{p}<0.05)$. The equilbrium moisture content $(\mathrm{EMC})$ of the wood samples decreased with heat treatment. The usual $11.8 \%$ moisture content of untreated wood was reduced to $5,7 \%$ in the samples treated at $220^{\circ} \mathrm{C}$ for $4 \mathrm{~h}$. 
Table 1. Effect of heat treatment on some physical properties of NLA wood.

\begin{tabular}{|c|c|c|c|c|c|c|c|c|c|}
\hline \multirow{2}{*}{$\begin{array}{c}\text { Temperature } \\
\left({ }^{\circ} \mathrm{C}\right)\end{array}$} & \multirow[t]{2}{*}{$\begin{array}{l}\text { Time } \\
\text { (h) }\end{array}$} & \multirow{2}{*}{$\begin{array}{r}\mathrm{pH} \\
5.7\end{array}$} & \multirow{2}{*}{$\begin{array}{c}\begin{array}{c}\text { EMC } \\
(\%)\end{array} \\
11.8 \\
\end{array}$} & \multicolumn{2}{|c|}{$\begin{array}{c}\text { Mass loss } \\
(\%)\end{array}$} & \multicolumn{2}{|c|}{$\begin{array}{l}\text { Air-dry density } \\
\left(\mathrm{g} / \mathrm{cm}^{3}\right)\end{array}$} & \multicolumn{2}{|c|}{$\begin{array}{l}\text { Oven-dry density } \\
\left(\mathrm{g} / \mathrm{cm}^{3}\right)\end{array}$} \\
\hline & & & & - & & $\begin{array}{c}0.77 \\
(0.01) \\
\end{array}$ & $c d$ & $\begin{array}{c}0.74 \\
(0.01) \\
\end{array}$ & cde \\
\hline \multirow{3}{*}{140} & 2 & 5.5 & 11.5 & $\begin{array}{c}0.52 \\
(0.05) \\
\end{array}$ & $a^{*}$ & $\begin{array}{c}0.76 \\
(0.01) \\
\end{array}$ & cde & $\begin{array}{c}0.75 \\
(0.02) \\
\end{array}$ & $d e$ \\
\hline & 4 & 5.3 & 11.4 & $\begin{array}{c}0.68 \\
(0.10)\end{array}$ & $a b$ & $\begin{array}{c}0.75 \\
(0.02)\end{array}$ & $d e$ & $\begin{array}{c}0.73 \\
(0.02)\end{array}$ & $b c d$ \\
\hline & 6 & 5.3 & 11.3 & $\begin{array}{c}1.05 \\
(0.10)\end{array}$ & $a b c$ & $\begin{array}{c}0.77 \\
(0.02)\end{array}$ & $d e$ & $\begin{array}{c}0.75 \\
(0.02) \\
\end{array}$ & $d e$ \\
\hline \multirow{3}{*}{180} & 2 & 5 & 10.3 & $\begin{array}{c}1.27 \\
(0.05) \\
\end{array}$ & $b c$ & $\begin{array}{c}0.79 \\
(0.03) \\
\end{array}$ & $e$ & $\begin{array}{c}0.77 \\
(0.02) \\
\end{array}$ & $e$ \\
\hline & 4 & 4.7 & 9.9 & $\begin{array}{c}1.45 \\
(0.03)\end{array}$ & $c$ & $\begin{array}{c}0.77 \\
(0.01)\end{array}$ & $d e$ & $\begin{array}{c}0.75 \\
(0.01)\end{array}$ & $d e$ \\
\hline & 6 & 4.4 & 8.8 & $\begin{array}{c}8.54 \\
(0.17)\end{array}$ & $d$ & $\begin{array}{c}0.74 \\
(0.02)\end{array}$ & $b c d$ & $\begin{array}{l}0.71 \\
(0.02)\end{array}$ & $b c$ \\
\hline \multirow{3}{*}{200} & 2 & 4.7 & 8.4 & $\begin{array}{l}12.71 \\
(0.28)\end{array}$ & $e$ & $\begin{array}{c}0.76 \\
(0.03)\end{array}$ & cde & $0.74(0.03)$ & cde \\
\hline & 4 & 4.2 & 8.3 & $\begin{array}{l}14.08 \\
(0.73) \\
\end{array}$ & $f$ & $\begin{array}{c}0.75 \\
(0) \\
\end{array}$ & de & $\begin{array}{r}0.73 \\
(0) \\
\end{array}$ & $b c d$ \\
\hline & 6 & 4.3 & 7.1 & $\begin{array}{l}17.15 \\
(0.81)\end{array}$ & $g$ & $\begin{array}{c}0.75 \\
(0.01) \\
\end{array}$ & $b c d$ & $\begin{array}{c}0.73 \\
(0.01) \\
\end{array}$ & $b c d$ \\
\hline \multirow{3}{*}{220} & 2 & 4.3 & 6 & $\begin{array}{l}17.01 \\
(0.75)\end{array}$ & $g$ & $\begin{array}{c}0.73 \\
(0.02) \\
\end{array}$ & $b c$ & $\begin{array}{c}0.71 \\
(0.02) \\
\end{array}$ & $b c$ \\
\hline & 4 & 3.9 & 5.7 & $\begin{array}{l}24.65 \\
(0.83)\end{array}$ & $h$ & $\begin{array}{c}0.69 \\
(0.07)\end{array}$ & $a$ & $\begin{array}{c}0.67 \\
(0.07)\end{array}$ & $a$ \\
\hline & 6 & 3.9 & 5.8 & $\begin{array}{l}27.38 \\
(0.48)\end{array}$ & $l$ & $\begin{array}{c}0.71 \\
(0.03)\end{array}$ & $a b$ & $\begin{array}{c}0.70 \\
(0.02)\end{array}$ & $a b$ \\
\hline
\end{tabular}

${ }^{*} \mathrm{p}<0.05$ (Duncan's test). Means within each column and factor followed by the same letter are not significantly different. Values in parenthesis are standart deviations. EMC: Equilbrium moisture content.

\section{Chemical Content}

The chemical compositions of the heat-treated and untreated samples are presented in table 2. The average holocellulose content in the untreated samples was $78.38 \%$. The holocellulose content decreased with a treatment duration of $2 \mathrm{~h}$ or more, with the lowest content occurring in samples treated at $220^{\circ} \mathrm{C}$ for 4 $(51.39 \%)$ and $6 \mathrm{~h}(50.59 \%)$. This decrease in holocellulose content was basically due to a loss of substantially hemicellulose. These results are in agreement with those of previous studies using other wood types (Fengel and Wegener 1989, Yildiz 2002, Hill 2006, Khalid et al. 2010). 
Table 2. Chemical characterization of NLA wood.

\begin{tabular}{|c|c|c|c|c|c|c|c|c|c|c|c|c|c|c|c|c|c|c|}
\hline \multirow{3}{*}{$\begin{array}{c}\text { Temp. } \\
\left({ }^{\circ} \mathrm{C}\right) \\
\text { Control }\end{array}$} & \multirow{3}{*}{$\begin{array}{l}\text { Time } \\
\text { (h) }\end{array}$} & \multirow{2}{*}{\multicolumn{2}{|c|}{$\begin{array}{c}\text { Holocellulose } \\
\text { (\%) }\end{array}$}} & \multirow{2}{*}{\multicolumn{2}{|c|}{$\begin{array}{c}\text { Cellulose } \\
(\%)\end{array}$}} & \multirow{3}{*}{$\begin{array}{c}\begin{array}{c}\text { Hemicellulose } \\
(\%)\end{array} \\
24.93\end{array}$} & \multirow{2}{*}{\multicolumn{2}{|c|}{$\begin{array}{l}\text { Lignin } \\
(\%)\end{array}$}} & \multirow{2}{*}{\multicolumn{2}{|c|}{$\begin{array}{l}\text { Ash } \\
(\%)\end{array}$}} & \multicolumn{8}{|c|}{ Solubility (\%) } \\
\hline & & & & & & & & & & & \multicolumn{2}{|c|}{$\begin{array}{c}\text { Hot } \\
\text { water }\end{array}$} & \multicolumn{2}{|c|}{$\begin{array}{l}\text { Cold } \\
\text { water }\end{array}$} & \multicolumn{2}{|c|}{$\begin{array}{l}\text { Alcohol } \\
\text { benzene }\end{array}$} & \multicolumn{2}{|c|}{$\begin{array}{c}1 \% \\
\mathrm{NaOH}\end{array}$} \\
\hline & & $\begin{array}{l}78.38 \\
(0.30)\end{array}$ & $f^{*}$ & $\begin{array}{l}53.45 \\
(0.21)\end{array}$ & $g$ & & $\begin{array}{l}21.40 \\
(0.09)\end{array}$ & $c d$ & $\begin{array}{c}0.83 \\
(0.02)\end{array}$ & $c d$ & $\begin{array}{c}5.14 \\
(0.75)\end{array}$ & $b c$ & $\begin{array}{c}6.33 \\
(0.69)\end{array}$ & $f g$ & $\begin{array}{c}4.18 \\
(1.17)\end{array}$ & $a b c$ & $\begin{array}{l}13.49 \\
(0.19)\end{array}$ & $a$ \\
\hline \multirow{3}{*}{140} & 2 & $\begin{array}{l}74.30 \\
(0.72)\end{array}$ & $e$ & $\begin{array}{l}52.51 \\
(1.42)\end{array}$ & $f g$ & 21.79 & $\begin{array}{l}21.76 \\
(0.07)\end{array}$ & $c d$ & $\begin{array}{c}1.10 \\
(0.44)\end{array}$ & $e$ & $\begin{array}{c}6.29 \\
(0.42)\end{array}$ & $d e$ & $\begin{array}{c}6.82 \\
(0.11)\end{array}$ & $g$ & $\begin{array}{c}5.43 \\
(0.09)\end{array}$ & de & $\begin{array}{l}14.84 \\
(0.08)\end{array}$ & $b$ \\
\hline & 4 & $\begin{array}{l}75.56 \\
(0.25)\end{array}$ & $e$ & $\begin{array}{l}50.59 \\
(0.12)\end{array}$ & cde & 24.97 & $\begin{array}{l}22.34 \\
(0.01)\end{array}$ & $d e$ & $\begin{array}{c}0.97 \\
(0.09)\end{array}$ & $d e$ & $\begin{array}{c}5.34 \\
(0.22)\end{array}$ & $b c$ & $\begin{array}{c}6.08 \\
(0.22)\end{array}$ & $e f g$ & $\begin{array}{c}4.03 \\
(0.03)\end{array}$ & $a b$ & $\begin{array}{l}15.46 \\
(0.10)\end{array}$ & $c$ \\
\hline & 6 & $\begin{array}{l}75.93 \\
(0.27)\end{array}$ & $e$ & $\begin{array}{l}52.65 \\
(0.58)\end{array}$ & $f g$ & 23.28 & $\begin{array}{l}19.89 \\
(0.34)\end{array}$ & $a b$ & $\begin{array}{c}1.34 \\
(0.11)\end{array}$ & $f$ & $\begin{array}{c}4.82 \\
(0.12)\end{array}$ & $a b$ & $\begin{array}{c}5.51 \\
(0.27)\end{array}$ & def & $\begin{array}{c}5.02 \\
(0.10)\end{array}$ & bcde & $\begin{array}{l}17.95 \\
(0.16)\end{array}$ & $d$ \\
\hline \multirow{3}{*}{180} & 2 & $\begin{array}{l}74.37 \\
(0.19)\end{array}$ & $e$ & $\begin{array}{l}51.45 \\
(0.16)\end{array}$ & def & 22.92 & $\begin{array}{l}19.52 \\
(0.51)\end{array}$ & $a$ & $\begin{array}{c}1.04 \\
(0.17)\end{array}$ & de & $\begin{array}{c}5.34 \\
(0.12)\end{array}$ & $b c$ & $\begin{array}{c}4.79 \\
(0.05)\end{array}$ & $b c d$ & $\begin{array}{c}3.80 \\
(0.09)\end{array}$ & $a$ & $\begin{array}{l}15.41 \\
(0.09)\end{array}$ & $c$ \\
\hline & 4 & $\begin{array}{l}74.01 \\
(1.12)\end{array}$ & $e$ & $\begin{array}{l}50.21 \\
(1.44)\end{array}$ & $c d$ & 23.8 & $\begin{array}{l}21.82 \\
(0.72)\end{array}$ & cde & $\begin{array}{c}0.60 \\
(0.13)\end{array}$ & $a b c$ & $\begin{array}{c}5.13 \\
(0.06)\end{array}$ & $a b$ & $\begin{array}{c}4.02 \\
(0.11)\end{array}$ & $a b$ & $\begin{array}{c}3.94 \\
(0.14)\end{array}$ & $a b$ & $\begin{array}{l}17.72 \\
(0.46)\end{array}$ & $d$ \\
\hline & 6 & $\begin{array}{l}66.37 \\
(0.33)\end{array}$ & $d$ & $\begin{array}{l}49.66 \\
(1.30)\end{array}$ & $c$ & 16.71 & $\begin{array}{l}20.95 \\
(0.32)\end{array}$ & $b c$ & $\begin{array}{c}0.47 \\
(0.11)\end{array}$ & $a b$ & $\begin{array}{c}5.28 \\
(0.07)\end{array}$ & $b c$ & $\begin{array}{c}4.91 \\
(0.05)\end{array}$ & $c d$ & $\begin{array}{c}4.24 \\
(0.08)\end{array}$ & $a b c$ & $\begin{array}{l}23.76 \\
(0.48)\end{array}$ & $f$ \\
\hline \multirow{3}{*}{200} & 2 & $\begin{array}{l}66.21 \\
(0.18)\end{array}$ & $d$ & $\begin{array}{l}50.61 \\
(0.35)\end{array}$ & cde & 15.6 & $\begin{array}{l}20.56 \\
(0.73)\end{array}$ & $a b c$ & $\begin{array}{c}0.55 \\
(0.17)\end{array}$ & $a b$ & $\begin{array}{c}5.77 \\
(0.16)\end{array}$ & $c d$ & $\begin{array}{c}5.90 \\
(0.61)\end{array}$ & $e f$ & $\begin{array}{c}4.09 \\
(0.12)\end{array}$ & $a b$ & $\begin{array}{l}21.70 \\
(0.26)\end{array}$ & $e$ \\
\hline & 4 & $\begin{array}{l}56.36 \\
(3.99)\end{array}$ & $c$ & $\begin{array}{l}53.39 \\
(0.38)\end{array}$ & $g$ & 2.97 & $\begin{array}{l}23.04 \\
(2.23)\end{array}$ & $e$ & $\begin{array}{c}0.54 \\
(0.02)\end{array}$ & $a b$ & $\begin{array}{c}6.56 \\
(0.04)\end{array}$ & $e$ & $\begin{array}{c}5.33 \\
(0.06)\end{array}$ & de & $\begin{array}{c}5.44 \\
(0.10)\end{array}$ & $d e$ & $\begin{array}{l}27.89 \\
(0.53)\end{array}$ & $g$ \\
\hline & 6 & $\begin{array}{l}53.99 \\
(0.30)\end{array}$ & $b$ & $\begin{array}{l}50.02 \\
(0.86)\end{array}$ & $c d$ & 3.97 & $\begin{array}{l}30.79 \\
(0.29)\end{array}$ & $f$ & $\begin{array}{c}0.70 \\
(0.03)\end{array}$ & $b c$ & $\begin{array}{c}7.70 \\
(0.37)\end{array}$ & $f$ & $\begin{array}{c}4.14 \\
(0.12)\end{array}$ & $a b c$ & $\begin{array}{c}6.15 \\
(0.07)\end{array}$ & $e f$ & $\begin{array}{l}34.93 \\
(0.56)\end{array}$ & $l$ \\
\hline \multirow{3}{*}{220} & 2 & $\begin{array}{l}54.78 \\
(0.16)\end{array}$ & $b c$ & $\begin{array}{l}51.36 \\
(0.67)\end{array}$ & def & 3.42 & $\begin{array}{l}34.40 \\
(0.62)\end{array}$ & $g$ & $\begin{array}{c}0.44 \\
(0.03)\end{array}$ & $a b$ & $\begin{array}{c}5.04 \\
(0.14)\end{array}$ & $b c$ & $\begin{array}{c}4.13 \\
(0.11)\end{array}$ & $a b c$ & $\begin{array}{c}4.33 \\
(0.13) \\
\end{array}$ & $a b c$ & $\begin{array}{l}28.15 \\
(0.37)\end{array}$ & $g$ \\
\hline & 4 & $\begin{array}{l}51.39 \\
(2.22) \\
\end{array}$ & $a$ & $\begin{array}{l}47.61 \\
(2.07) \\
\end{array}$ & $a b$ & 3.78 & $\begin{array}{l}37.47 \\
(0.15) \\
\end{array}$ & $h$ & $\begin{array}{c}0.43 \\
(0.02) \\
\end{array}$ & $a$ & $\begin{array}{c}4.20 \\
(0.11) \\
\end{array}$ & $a$ & $\begin{array}{c}4.06 \\
(0.86) \\
\end{array}$ & $a b$ & $\begin{array}{c}5.27 \\
(0.16) \\
\end{array}$ & $c d e$ & $\begin{array}{l}34.24 \\
(0.26) \\
\end{array}$ & $h$ \\
\hline & 6 & $\begin{array}{l}50.59 \\
(0.21)\end{array}$ & $a$ & $\begin{array}{l}48.15 \\
(1.50)\end{array}$ & $b$ & 2.44 & $\begin{array}{l}41.15 \\
(0.91)\end{array}$ & $i$ & $\begin{array}{c}0.42 \\
(0.04)\end{array}$ & $a$ & $\begin{array}{c}4.81 \\
(0.33)\end{array}$ & $a b$ & $\begin{array}{c}3.67 \\
(0.13)\end{array}$ & $a$ & $\begin{array}{c}7.14 \\
(0.60)\end{array}$ & $f$ & $\begin{array}{l}36.37 \\
(0.36)\end{array}$ & $j$ \\
\hline
\end{tabular}

${ }^{*} \mathrm{p}<0.05$ (Duncan's test). Means within each column and factor followed by the same letter are not significantly different.

Values in parenthesis are standart deviations.

The lignin content was not significantly changed until the treatment temperature reached $200^{\circ} \mathrm{C}$ for at least $2 \mathrm{~h}$. This result is in agreement with that of a previous study (Yildiz 2002). The relative lignin content of the untreated samples was $21.4 \%$, whereas it was significantly greater in the samples treated at $200^{\circ} \mathrm{C}$. The highest lignin content $(41.15 \%)$ was observed in samples treated at $220^{\circ} \mathrm{C}$ for $6 \mathrm{~h}$ an increase of $\sim 92 \%$ compared with the untreated. Of the main components of wood, lignin is the most resistant to thermal degradation (Fengel and Wegener 1989). The relative increase in lignin content with heat treatment is associated with structural changes (cross-linking) in lignin composition (Esteves et al. 2008, Boonstra and Tjeerdsma 2006). Lignin also undergoes polycondensation reactions with other cell wall components (Esteves et al. 2008). Thus, the lignin content increases propotionally with a decreasing polysaccharide (cellulose and especially hemicelluloses) content (Kotilainen 2000).

The mean relative hemicellulose content of the samples heated to 140 or $180^{\circ} \mathrm{C}$ for 2 and $4 \mathrm{~h}$ was similar to that of the control samples. However, the mean hemicellulose content decreased significantly with a treatment temperature of $200^{\circ} \mathrm{C}$ for $4 \mathrm{~h}$. The loss of hemicellulose was $84-90 \%$ greater in the heat-treated samples than in the controls. The lowest hemicellulose content $(2,4 \%)$ was observed in samples treated at $220^{\circ} \mathrm{C}$ for $6 \mathrm{~h}$. In contrast to these results, Sivonen et al. (2002) showed that hemicelluloses are affected by heat treatment even at relatively low temperatures; however, similar to our results, the hemicellulose content decreased with increasing treatment temperature and time compared to the controls. 
The mean cellulose content of untreated NLA control samples was $53.45 \%$. Although the cellulose content decreased slightly at treatment temperatures below $220^{\circ} \mathrm{C}$, the decline was not linearly correlated with the treatment temperature and duration. The decrease in cellulose content following treatment at $220^{\circ} \mathrm{C}$ for 6 $\mathrm{h}$ was only $\sim 11 \%$ compared to the controls. Cellulose undergoes limited deformation with heat treatment due to its high molecular weight crystalline structure. Especially, the amorphous structure of cellulose is probably deformed at tempreature above $200^{\circ} \mathrm{C}$ (Bhuiyan and Hirai 2005). As a result, the slight decrease in cellulose content at temperatures above $200^{\circ} \mathrm{C}$ (Sundqvist 2004). The amount of components soluble in $1 \% \mathrm{NaOH}$ increased linearly during heat treatment (Table 2). The relative content of $1 \% \mathrm{NaOH}$-soluble components was $13.49 \%$ in the control samples and $28 \%$ in the samples heated to $200^{\circ} \mathrm{C}$ for $4 \mathrm{~h}$. Even at the lowest treatment temperature of $140^{\circ} \mathrm{C}$ for $2 \mathrm{~h}$, the content of $1 \% \mathrm{NaOH}$-soluble components increased $10 \%$ relative to the controls. This increase probably resulted from the dissolution of carbohydrate, the lightest $1 \% \mathrm{NaOH}$-soluble component in wood considering its molecular mass (Tümen et al. 2010). The relative content of hot water-soluble components increased slightly with increasing heat treatment up to $220^{\circ} \mathrm{C}$ and then decreased by $\sim 18 \%$ after $4 \mathrm{~h}$ at $220^{\circ} \mathrm{C}$ compared to the controls. A previous study (Yildiz 2002) found that the relative content of hot water-soluble components decreased with temperatures ranging from 180 to $200^{\circ} \mathrm{C}$. The relative content of alcohol-benzene (2:1) extractable components was $4.18 \%$ in the controls. This content increased with increasing treatment temperature and duration. The greatest content of alcoholbenzene-extractable components was observed in the samples heated to $220^{\circ} \mathrm{C}$ for $6 \mathrm{~h}(7.14 \%)$, which is a $71 \%$ increase over controls.

In summary, the data in table 3 show that treatment temperature and duration significantly $(\mathrm{p}<0.05)$ affected the holocellulose, cellulose, hemicellulose, lignin, hot water-extractable, alcohol-benzene-extractable and 1\% $\mathrm{NaOH}$-extractable components of NLA wood.

Table 3. ANOVA of the chemical content of heat-treated NLA wood with different treatment parameters.

\begin{tabular}{llcccc}
\hline \multirow{2}{*}{ Dependent Variable } & $\begin{array}{l}\text { Source of } \\
\text { variance }\end{array}$ & $\begin{array}{c}\text { Sum of } \\
\text { Squares }\end{array}$ & df & F & Sig.* \\
\hline \multirow{2}{*}{ Holocellulose } & Temperature & 2348.8 & 3 & 534 & 0.000 \\
& Time & 1931 & 3 & 439 & 0.000 \\
\hline \multirow{2}{*}{ Cellulose } & Temperature & 81.4 & 3 & 30.4 & 0.000 \\
& Time & 118.6 & 3 & 44.2 & 0.000 \\
\hline \multirow{2}{*}{ Hemicellulose } & Temperature & 1261.4 & 3 & 858.3 & 0.000 \\
& Time & 304.5 & 3 & 207.2 & 0.000 \\
\hline \multirow{2}{*}{ Lignin } & Temperature & 1261.4 & 3 & 858.3 & 0.000 \\
& Time & 304.5 & 3 & 207.2 & 0.000 \\
\multirow{2}{*}{ Hot water } & Temperature & 14.3 & 3 & 27 & 0.000 \\
& Time & 2.2 & 3 & 4.1 & 0.014 \\
\multirow{2}{*}{ Alcohol-benzene } & Temperature & 9.4 & 3 & 8.4 & 0.000 \\
& Time & 14.7 & 3 & 13.2 & 0.000 \\
\multirow{2}{*}{$1 \% \mathrm{NaOH}$} & Temperature & 1249.2 & 3 & 4088.4 & 0.000 \\
& Time & 1407.6 & 3 & 4606.9 & 0.000 \\
\hline
\end{tabular}

*p $<0.05$ (Duncan's test). 


\section{Biological Performance}

The mass losses in the control samples exposed to various decay fungi were $41.3 \%$ with $T$. versicolor, $23.3 \%$ with $S$. lacrymans, $36.2 \%$ with C. puteana, and $31.7 \%$ with G. trabeum (Table 4).

Table 4. Percent mass loss in heat-treated samples of NLA wood after exposure to various decay fungi.

\begin{tabular}{|c|c|c|c|c|c|c|c|c|c|}
\hline \multirow{2}{*}{$\begin{array}{c}\text { Temperature } \\
\left({ }^{\circ} \mathrm{C}\right)\end{array}$} & \multirow{3}{*}{$\begin{array}{l}\text { Time } \\
\text { (h) }\end{array}$} & \multicolumn{8}{|c|}{ Mass loss (\%) } \\
\hline & & \multicolumn{2}{|c|}{ T. versicolor } & \multicolumn{2}{|c|}{ S. lacrymans } & \multicolumn{2}{|c|}{ C. puteana } & \multicolumn{2}{|c|}{ G. trabeum } \\
\hline Control & & $41.3(2.1)$ & $i^{*}$ & $23.3(3.7)$ & $e$ & $36.2(2.8)$ & $h$ & $31.7(3.3)$ & $e$ \\
\hline \multirow{3}{*}{140} & 2 & $37.0(3.5)$ & $h$ & $23.6(2.5)$ & $e$ & $32.3(2.2)$ & $f g$ & $31.1(2.3)$ & $e$ \\
\hline & 4 & $38.0(1.8)$ & $h i$ & $17.7(5.1)$ & $d$ & $34.2(1)$ & $g h$ & $33.5(2.9)$ & $e$ \\
\hline & 6 & $31.1(2.8)$ & $g$ & $15.5(4)$ & $d$ & $33.4(0.5)$ & $f g$ & $31.8(3.6)$ & $e$ \\
\hline \multirow{3}{*}{180} & 2 & $32.3(1.1)$ & $g$ & $15.1(4.9)$ & $d$ & $31.1(5.1)$ & $f$ & $33.5(2.8)$ & $e$ \\
\hline & 4 & $35.7(3.7)$ & $h$ & $7.3(0.7)$ & $b c$ & $21.7(0.1)$ & $e$ & $26.8(3)$ & $d$ \\
\hline & 6 & $27.1(3)$ & ef & $7.3(0.5)$ & $b c$ & $21.4(0.2)$ & $e$ & $24.8(1.6)$ & $d$ \\
\hline \multirow{3}{*}{200} & 2 & $30(4.2)$ & $f g$ & $8.8(0.9)$ & $c$ & $14.9(0.7)$ & $d$ & $16.7(1.2)$ & $c$ \\
\hline & 4 & $26.3(3.3)$ & de & $4.7(0.8)$ & $a b$ & $9.3(0.2)$ & $c$ & $16.5(4)$ & $c$ \\
\hline & 6 & $20.1(3.8)$ & $b c$ & $2.6(1.7)$ & $a$ & $7.9(2.2)$ & $b c$ & $10.1(0.4)$ & $b$ \\
\hline \multirow{3}{*}{220} & 2 & $23.2(3.7)$ & $c d$ & $1.2(0.3)$ & $a$ & $5.5(0.5)$ & $b$ & $9.7(0.1)$ & $b$ \\
\hline & 4 & $17.4(1.7)$ & $b$ & $1.2(0.3)$ & $a$ & $2.5(1.6)$ & $a$ & $5.3(0.5)$ & $a$ \\
\hline & 6 & $14.1(2)$ & $a$ & $1(0.5)$ & $a$ & $0.2(0.2)$ & $a$ & $2.9(0.2)$ & $a$ \\
\hline
\end{tabular}

${ }^{*} \mathrm{p}<0.05$ (Duncan's test). Means within each column and factor followed by the same letter are not significantly different. Values in parenthesis are standart deviations.

In the heat-treated samples exposed to T. versicolor (white decay fungus), the lowest mass losses occurred in the samples treated at $220^{\circ} \mathrm{C}$ for 4 and $6 \mathrm{~h}(17.4$ and $14.1 \%$, respectively). No significant change in mass loss was observed in samples treated at 140 and $180^{\circ} \mathrm{C}$, regardless of the duration.

In samples exposed to $S$. lacrymans (dry decay fungus), the mass loss was significantly reduced in samples treated at $180^{\circ} \mathrm{C}$ for $4 \mathrm{~h}$. At lower temperatures, the results were mixed. The lowest mass losses $(<1.2 \%)$ were observed in samples treated at $220^{\circ} \mathrm{C}$ for 4 and $6 \mathrm{~h}$. S. lacrymans is selectively depolymerises the cellulose and hemicellulose components of wood due to its actually a brown rot fungi (Hibbett and Donoghue 2001). In the samples exposed to C. puteana or G. trabeum (brown decay fungi), no significant change in mass loss occurred unless the treatment temperature was at least $180^{\circ} \mathrm{C}$ for $4 \mathrm{~h}$. At $200^{\circ} \mathrm{C}$ for $4 \mathrm{~h}$, the average mass loss was reduced to $9.3 \%$ with $C$. puteana and $16.5 \%$ with G. trabeum. For both species, the lowest mass losses were observed in samples treated at $220^{\circ} \mathrm{C}$ for 4 and $6 \mathrm{~h}$ (Table 4).

Table 5 shows the results of a multiple variance analysis of the effects of treatment temperature and duration on mass loss. Both temperature and duration significantly affected the mass losses of the samples. 
Table 5. ANOVA of the effect of treatment temperature and duration on mass loss in NLA wood after exposure to various decay fungi.

\begin{tabular}{llcccc}
\hline Dependent Variable & $\begin{array}{l}\text { Source of } \\
\text { variance }\end{array}$ & $\begin{array}{l}\text { Sum of } \\
\text { Squares }\end{array}$ & df & F & Sig.* \\
\hline \multirow{2}{*}{ T. versicolor } & Temperature & 2025.0 & 3 & 32.9 & 0.000 \\
\multirow{2}{*}{ S. lacrymans } & Time & 4140.5 & 3 & 67.4 & 0.000 \\
\hline \multirow{2}{*}{ C. puteana } & Temperature & 2357.5 & 3 & 95.9 & 0.000 \\
& Time & 4183.6 & 3 & 170.2 & 0.000 \\
\hline \multirow{2}{*}{ G. trabeum } & Temperature & 7503.5 & 3 & 67.3 & 0.000 \\
& Time & 6252.7 & 3 & 56.1 & 0.000 \\
\hline
\end{tabular}

${ }^{*} \mathrm{p}<0.05$ (Duncan's test).

These differences in mass loss are directly correlated with the changes in chemical composition of the wood with heat treatment. During heat treatment, significant degradation of amorphous polysaccharides occurs at the cell membrane, and the hygroscopicity of the wood decreases (Esteves and Pereira 2009). Furthermore, with a reduction in the relative content of nutrients for decay fungi, resistance against the fungi increases (Esteves and Pereira 2009). We observed a reduction of as much as $90 \%$ in the hemicellulose content, depending on the treatment temperature and duration (Table 2). However, the relative lignin content increased proportionally to $48 \%$. Hemicelluloses are highly sensitive to heat treatment, and in many studies losses occurred from the start of heat treatment (Weiland and Guyonnet 2003, Hakkou et al. 2006). Accordingly, lignin cross-linking and the lignin content both increase with heat treatment (Hakkou et al. 2006, Khalid et al. 2010). As known, while brown rot fungi are characterized by the removal of the polysaccharide components, white rot fungi degrade lignin and polysaccharides simultaneously (Hill 2006). Therefore, the decay resistant of NLA wood was increased not only brown rot, but also white rot fungi by heat treatment.

Additionally, The reduction in equilibrium moisture content decreases the wettability of wood and affects the enzymatic activities of fungi (Viitaniemi and Jämsä 1996, Kamdem et al. 2002, Almeida et al. 2009). Therefore, this factor should also increase the resistance of the wood to decay fungi. Another factor affecting the fungal resistance of the wood is $\mathrm{pH}$. The natural $\mathrm{pH}$ of 5.7 was reduced to 3.9 in the heat-treated wood. The optimum $\mathrm{pH}$ for fungal growth is 5-6 (Bozkurt et al.1993). Thus, heat treatment made the $\mathrm{pH}$ less favorable for fungal growth.

Finally, fungicidal extractives are produced during heat treatment (Kamdem et al. 2000). Although we observed no linear increase in certain extractable components (hot water, cold water, and alcohol-benzene) of the wood samples with heat treatment, we did observe a linear increase in $1 \% \mathrm{NaOH}$-soluble components with increasing treatment temperature and duration. 


\section{CONCLUSIONS}

Heat treatment also causes a loss of mass in NLA wood. At temperatures of $180^{\circ} \mathrm{C}(6 \mathrm{~h})$ and above these mass losses increased with increasing temperature and duration. The equilibrium moisture content of the wood also decreased with increasing treatment temperature and duration.

Heat treatment causes various changes in the chemical composition of NLA wood depending on the treatment temperature and duration. While the holocellulose content decreases at temperatures of $200^{\circ} \mathrm{C}$ and above, the lignin content increases proportionally. The hemicellulose content begins to decrease at relatively low temperatures and undergoes an extensive decline following treatment at $220^{\circ} \mathrm{C}$ for $4 \mathrm{~h}$.

In these experiments, the heat-treated NLA wood became more resistant to four different species of decay fungi. While no significant change was observed in the mass losses caused by fungi up to a treatment temperature of $180^{\circ} \mathrm{C}$, a significant decrease was observed at higher temperatures. This increase in resistance also increased with an increasing duration of heat treatment at the higher temperatures. This reduction in mass loss was correlated with the decrease in equilibrium moisture content of the wood and with the changes in the wood's chemical composition.

NLA is a fast-growing species with high economic value, but its wood has a low degree of natural durability. We conclude, however, that the durability of NLA wood against fungi can be increased through heat treatment, an environmentally friendly method of preservation, thereby increasing the wood's utility for various applications such as garden furniture, pool areas, flooring, siding, decks etc.

\section{REFERENCES}

Almeida, G.; Brito, J.O.; Perré, P. 2009. Changes in wood-water relationship due to heat treatment assessed on micro-samples of three Eucalyptus species. Holzforschung 63(1):80-88.

Bhuiyan, T.; Hirai, N. 2005. Study of crystalline behaviour of heat-treated wood cellulose during treatments in water. Journal of Wood Science 51(1):42-47.

Boonstra, M.; Tjeerdsma, B. 2006. Chemical analysis of heat-treated softwoods. Holz als Roh-und Werkstoff 64: 204-211.

Bozkurt, A. Y.; Erdin, N. 1989. Ticarette önemli yabancı ağaçlar. İstanbul Üniversitesi Fen Bilimleri Enstitüsü, Yayın No. 357214, İstanbul.

Bozkurt, A. Y.; Göker, Y.; Erdin, N. 1993. Emprenye tekniği. İstanbul Üniversitesi Orman Fakültesi, Yayın No:3779, İstanbul.

Browning, B. L. 1967. Methods of wood chemistry. Volume 2, Wiley-Interscience, New York.

Calonego, F. W.; Severo, E. T. D.; Furtado, E. L. 2010. Decay resistance of thermally-modified Eucalyptus grandis wood at $140^{\circ} \mathrm{C}, 160^{\circ} \mathrm{C}, 180^{\circ} \mathrm{C}, 200^{\circ} \mathrm{C}$ and $220^{\circ} \mathrm{C}$. Bioresource Technology 101(23):9391-9394.

Cao, Y.; Lu, J.; Huang, R.; Zhao, Y.; Wu, Y. 2011. Evaluation of decay resistance for steam-heat-treated wood. Bioresources 6(4):4696-4704. 
Cicek, E.; Yilmaz, M. 2002. The importance of Fraxinus angustifolia subsp. oxyacarpa as a fast growing tree for Turkey. IUFRO Meeting on Management of Fast Growing Plantations, Izmit, 192-202.

Esteves, B.; Pereira, H. 2009. Wood modification by heat treatment: Review. Bioresources 4(1):370-404.

Esteves, B.; Marques, A.V.; Domingos, I.; Pereira, H. 2008. Heat-induced colour changes of pine (Pinus pinaster) and eucalypt (Eucalyptus globulus) wood. Wood Science and Technology 42(5):369-384.

European standard EN 1131996. Wood preservatives. Test method for determining the protective effectiveness against wood destroying basidiomycetes-determination of the toxic values.

Fengel, D.; Wegener, G. 1989. Wood: Chemistry, ultrastructure, reactions. Walter de Gruyter and Company, Berlin.

González-Peña, M.; Breese, M.; Hill, C. 2004. Hygroscopicity in heat-treated wood: effect of extractives. In: International Conference on Environmentally Compatible Forest Products (ICECFOP), 22- 24 September, Leicester UK, 105-119.

Hakkou, M.; Pétrissans, M.; Zoulalian, A.; Gérardin, P. 2005. Investigation of wood wettability changes during heat treatment on the basis of chemical analysis. Polymer Degradation and Stability 89(1):1-5.

Hakkou, M.; Pétrissans, M.; Gérardin, P.; Zoulalian, A. 2006. Investigations of the reasons for fungal durability of heat-treated beech wood. Polym Degrad Stabil 91(2):393-397.

Hibbett, D.S.; Donoghue, M.J. 2001. Analysis of character correlations among wood decay mechanisms, mating systems, and substrate ranges in homobasidiomycetes. Systematic Biology 50:215-242.

Hill, C. 2006. Wood modification chemical, thermal and other processes. Wiley series in renewable resources. Wiley and Sons Ldt, USA.

Homan, W.; Tjeerdsma, B.; Beckers, E.; Jorissen, A. 2000. Structural and other properties of modified wood. In: World Conference on Timber Engineering, British Columbia, Canada, pp 8.

Kamdem, D.P.; Pizzi, A.; Triboulot, M.C. 2000. Heat-treated timber: potentially toxic byproducts presence and extent of wood cell wall degradation. Holz als Roh- und Werkstoff 58(4): 253-257.

Kamdem, D.P.; Pizzi, A.; Jermannaud, A. 2002. Durability of heat-treated wood. Holz als Roh- und Werkstoff 60(1):1-6.

Kartal, S.N.; Munir, E.; Kakitani, T.; Imamura, Y. 2004. Bioremediation of CCA-treated wood by brown-rot fungi Fomitopsis palustris, Coniophora puteana and Laetiporus sulphureus. Journal of Wood Science 50(2):182-188.

Khalid, I.; Wahab, R.; Sudin, M.; Sulaiman, O.; Hassan, A.; Alamjuri, R.H.; Mojiol, A.R. 2010. Chemical changes in 15 year old cultivated Acacia hybrid oil-heat treated at 180,200 , and $220^{\circ} \mathrm{C}$. International Journal of Chemistry 2(1):97-107.

Kotilainen, R. 2000. Chemical changes in wood during heating at $150-260^{\circ} \mathrm{C}$. Ph.D. Thesis, University of Jyväskylä, Finland. 
Lekounougou, S.; Pétrissans, M.; Jacquot, J.P.; Gelhaye, E.; Ge'rardin, P. 2009. Effect of heat treatment on extracellular enzymatic activities involved in beech wood degradation by Trametes versicolor Wood Science and Technology 43(3-4):331-341.

Oliveira, A.M.F.; Lelis, A.T.; Lepage, E.S. 1986. Agentes destruidores de madeira. In: Lepage, E.S. (Coord.) Manual de Preservação de madeiras, São Paulo, 99-275.

Paes, J.B.; Morais, V.M.; de Lima, C.R. 2004. Resistência natural de nove madeiras do semi-árido brasileiro a fungos xilófagos em condições de laboratório. Revista Árvore 28(2):275-282.

Pettersen, R.C. 1984. The chemical composition of wood. In: Rowel, R.M. (Ed.), The Chemistry of Wood. Advances in Chemistry Series 207, American Chemical Society, Washington, DC, USA, 57-126.

Sivonen, H.; Maunu, S.L.; Sundholm, F.; Jamsa, S.; Viitaniemi, P. 2002. Magnetic resonance studies of thermally modified wood. Holzforschung 56(6):648-654.

Sundqvist, B. 2004. Colour changes and acid formation in wood during heating. Ph.D. Thesis, Lulea University of Thechnology, Sweden.

Sundqvist, B.; Westermark, U.; Eriksson, G. 2006. Cellulose degradation during hydrothermal treatment of birch wood (Betula pubescens Ehrh.). Cellulose Chemistry and Technology 40(3-4):217-221.

TAPPI Standarts. 1983. Cold extraction method for hydrogen ion concentration $(\mathrm{pH})$ of paper extracts, T 509 om-83, Atlanta, USA.

TAPPI Standarts. 1985. Sampling and preparing wood for analysis, T $257 \mathrm{~cm}-85$, Atlanta, USA.

TAPPI Standarts. 1988. Preparation of wood for chemical analysis, T 264 om-88, Atlanta, USA.

TAPPI Standarts. 1988. Wood extractives in ethanol-benzene mixture, T 204 om-88, Atlanta, USA.

TAPPI Standarts. 1988. One percent sodium hydroxide solubility of wood and pulp, T 212 om- 88 , Atlanta, USA.

TAPPI Standarts. 1988. Water solubility of wood and pulp, T 207 om-88, Atlanta, USA.

TAPPI Standarts. 1988. Acid insoluble lignin in wood and pulp, T 222 om-88, Atlanta, USA.

Turkish Standarts. TS 2005. Wood-determination of density for physical and mechanical tests, TS 2472, Ankara, Turkey.

Tumen, I.; Aydemir, D.; Gunduz, G.; Uner, B.; Cetin, H. 2010. Changes in the chemical structure of thermally treated wood. Bioresources 5(3):1936-1944.

Viitaniemi, P.; Jamsa, S. 1996. Modification of wood with heat treatment. Rep. no. 814, VTT Building Technology, Espoo, Finland.

Viitaniemi, P.; Jämsä, S.; Koskela, K.; Paajanen, L.; Vuorinen, T.; Maunu, S.; Paakkari, T. 2002. Reaction mechanisms of modified wood. Finnish Forest Cluster Reseach Programme Wood Wisdom (19982001), Final report, Paavilainen, L. (ed.). Helsinki, 185-192. 
Weiland, J.; Guyonnet, R. 2003. Study of chemical modifications and fungi degradation of thermally modified wood using DRIFT spectroscopy. Holz als Roh-und Werkstoff 61: 216-220.

Wise, E.L.; Karl, H.L. 1962. Cellulose and hemicelluloses in pulp and paper science and technology. Vol. 1, Pulp, Earl, C.L. (Ed.). McGraw Hill-Book Co., New York.

Yildiz, S. 2002. Physical, mechanical, technologic and chemical properties of Fagus orientalis and Picea orientalis wood treated by heating. Ph.D. Thesis, Karadeniz Technical University, Trabzon. 